\title{
Analysis of Labor Force Management to Arrange the Affective Employment Policy in Indonesia
}

\author{
Wahyuningrat \\ Departemen of Public Administrtion \\ Universitas Jenderal Soedirman \\ Purwokerto, Indonesia \\ wahyupwt@yahoo.com
}

\begin{abstract}
Labor force is the strategic resource and competitive potentiality for nation, but still many of the labor force management practice that has not placed the labor force as the strategic resource. Through the management practice analysis of labor forced it is hopefully it can formulate the effective policy. The purpose of this research is to analyze the management function oflabor force and identifies the recommendation for the effective policy. Research is conducted in Regency of Batang, Province of Central Java by using the approach of qualitative and its focus is the management function of labor force that become the responsibility of government. Result of research shows there has not the labor force plan because it has not the information system of employment. The budget of labor force management is very low so the performance of management function is low. The obedience of company in the industrial relationship, wage, and prosperity are still low. The ratio of the total controller with the total companies $1: 184$, so it causes the low of the company obedience. It needs the review again to the labor force policy in Indonesia.
\end{abstract}

Keyword: employment policy, labor force management

\section{INTRODUCTION}

Public policy in the perspective of public administration is a success key in achieving the nation's goal, because in every public policy is supposed to be formulated, implemented, and evaluated as good as possible. And also with the manpower policy is supposed to be made effectively in order to the competition of labor force can contribute to the achievement of nation's goal that is nation's prosperity. Labor force is the strategic resource and competitive potentiality that are not easy disappeared like technology [1]. In reality there are many of the management practice that has not put the labor force as the strategic resource. The treatment that is not fair to the women labor force still happens [2]; [3]. This phenomenon reflects that labor force has notbeing managed well. It is still continuing, so nation will lose the competitive superiority potential. Through the practice analysis of labor force management, it is hopefully for the government can formulate the effective policy.

This research was conducted at Regency of Batang, Province of Central Java, because in this regency there are many of the labor force disputes as the result of ineffective policy. This disputes was explained in the Regional Middle Term Development Plan (RPJMD) Regency of Batang in 2012-2017 that is (1) high of the total unemployment (7.11\%); (2) high of the work dependence concentration in the sector of agriculture; (3) low of the quality and productivity of labor force; and (4) there has not been optimum for the protection and development of labor force. Besided that, Regency of Batang is the regency which is under the north region of Java Island and this region is the movement tract of national economy of Indonesia.

Analysis of labor force management in this research focus on the management function of labor force that is conducted by government. According to the Act Number 13 in 2003[4] about Employment, management function of labor force which explains: (1) labor force plan and information system of employment; (2) work training and development; (3) placement of labor force; (4) distribution of labor force change; (5) labor force protection; (6) wage; (7) prosperity; (8) industrial relationship; (9) discharge of work relationship; and (10) controlling.

\section{RESEARCH METHODOLOGY}

This research uses the approach of qualitative by taking location in Regency of Batang, Province of Central Java. Design of research is grounded theory (Strauss \& Corbin, 1990). Focus of research is the functions of labor force management that becomes the responsibility of government as explained in the previous explanation. Data collection uses the technique of in-depth interview, non-participant observation, and documentation. Data analysis uses technique of grounded theory paradigm [5] and its legality is tested by using technique of checking from [6] that consists of credibility, transferability, dependability, and confirmability.

\section{RESULTS AND DISCUSSION}

\section{A. Labor Force Plan and Employment Information System}

The Act Number 13 in 2003 [4] stated, in order to the employment development, government determines the policy and arrange the labor force plan. Government of Batang has arranged the policy and program of employment as following: (1) arranges the technical plan in the employment field; (2) puts and empowers the labor force that involves the distribution of labor force information; (3) counseling of industrial relationship such as counseling of prevention of work accident. Checking of work accident, investigation of the norm violation of safety and health in the work place; (5) controlling implementation of manpower norm, training and 
putting the female work and children and labor force social guarantee; (6) implementation of work training, counseling to the work training institution, implementation of security and controlling to the work training institution; (7) increment of the work productivity, monitoring, and evaluation; (8) empowerment of the physical defect labor force; (9) development and distribution of the work opportunity and unemployment prevention; and (10) counseling and service of the labor force field license.

In contrary for the labor force plan, Government of the Regency of Batang has not been arranged. Labor force plan is the deploying of the labor force figure in the future in Regency of Batang that will be established. It means the policy and program of labor force that has been established in fact it is not based on the labor force plan, but it is just based on the problem of labor force. The absent of labor force plan in fact it is caused by the absent of the labor force information system.

\section{B. Training and Development}

According to Act Number 13 in 2003 [4], Government of the Regency of Batang has Work Training Institution (BLK). Normatively, the BLK equipment involve trainer, curriculum, infrastructures and fund. The government of the Regency of Batang has not fix trainer. If it needs trainer, they will invite the trainer from the private trainer institution. Curriculum is adjusted with the subject of requirement: 240 hours learning for the subject of computer operator, computer technician, sew, knit, make up, bridge make up, motor cycle technician. Car technician, body repair, and weld, and 120 hours for bakery, car drive, and batik. These infrastructures of BLK is complete that based on the learning that been given in curriculum. Fund comes from the Regional Expenditure and Income Budget (APBD) Regency of Batang it is Rp. $120,000,000.00$; per year or it is Rp. 10,000,000.00; per month. This fund is very small if compared with the total labor force that needs the training it is 14,750 peopl in 2014.

The activity of counseling involves the work training and labor force counseling it is intended to increase the relevance, quality, and efficiency of work training and productivity. Counseling strategy of work training in the Government of the Regency of Batang is by inserting to the training participants and the training implementer of productive culture, work performance, technology, and economy activity efficiency, it is to achieve the national productivity.

\section{Labor Force Deployment}

The Act Number 13 in 2003 [4] stated, in every of labor force has the similar right and opportunity to choose, get, or change to the other work and get the disserved income in the domestic or foreign countries. Related with work deployment, The Government of the Regency of Batang implements the opened principal, free, objective, and fair, and similar without discrimination. The service of labor force deployment that has been conducted by the Government of the Regency of Batang involves: (1) work deployment service AKL (Local Labor Force Period) it is the labor force deployment in Company in the area of
Central java Province; (2) deployment service of AKAD (Labor Force Period between Regional); (3) labor force deployment in the foreign country through the Private Implementer of Labor Force Deployment of Indonesia (PPTKIS). The service performance of labor force deployment in the Government of the Regency of Batang can be seen from the difference between the total of labor force applicant and with the total of labor force who have not been deployed. Total work applicant in 2014 is 14, 750 people, meanwhile labor force that has not be deployed is 9,602 people. So the performance of work deployment is 5,148 (34.90\%) which can be deployed.

\section{Training and Development}

The Act Number 13 in 2003 [4] stated, the government is responsible for the distribution of work opportunity whether in the domestic or foreign country. The Service of the Government of Batang is the distribution of work opportunity in outside of work relationship or through the informal sector activity that involves the counseling and increment of new entrepreneur, autonomous labor force, and appropriate technology. The counseling and increment of personal entrepreneur in 2014 is 210 people, autonomous labor force is 40 people and appropriate technology is 40 people. The activity participant is them who has business embryo and has the strong entrepreneur spirit and they has the interest to increase their business continuously.

\section{E. Labor Force Protection}

The Act Number 13 in 2003 [4] explained, this protection is proposed especially to the physical defect labor force, children labor force, female labor force, work time, safety and health of work. The Government of the Regency of Batang has not formulated the policy or program for the physical defect labor force. Related with the children labor force protection, The Government of the Regency of Batang has conduct these function optimally with the logo "Regency of Batang is the Regency of Disserved Children".

Related with the protection of female labor force and work time, it is more directed to the controlling function. The Government of the Regency of Batang also has conducted the protection of reproduction function that is by banning to the entrepreneurs to deploy the children labor force, pregnant female laborforce that according to the doctor it endangers for health and safety of her pregnancy it works between at 23.000 to 07.00. The other protection is Safety and Health of Work (K3). The form of its protection, the government obligates to all the entrepreneurs to conduct the management of K3. The protection of $\mathrm{K} 3$ is also implemented through the policy and program of zero accident.

\section{F. Wage}

The Act Number 13 in 2003 [4] stated, every labor force has right to get the income which can fulfill the disserved human needs. The Government of the Regency of Batang implements some of activities that are by establishing the Wage Board. The Duty of Wage Board gives suggestion, consideration, and formulates the wage policy in 
Regency of Batang. The subsequent activity conducts survey of Disserved Life Need (KHL) every month for 10 month in 4 markets in area of the Regency of Batang. Its purpose is to determine the Regency Minimum Wage (UMK) bases on the development of market price. The amount of UMK subsequently is proposed to the Governor of Central Java about the Regency Minimum Wage in the Province of Central Java. In 2014 UMK in Regency of Batang bases on the Decision of Governor of Central java Number 560/60 in 2013 about Minimum Wage in 35 Regency/City in province of Central java in2014 it is $1,146,000 ; /$ month. After that the entrepreneur must pay to the labor force in the minimum of UMK, but in the end 2014, the entrepreneur who pays bases on new UMK just reach $75 \%$. The other activity is by giving the education about the wage for labor force. Through this activity, the labor force hopefully can count labor force work, so it will be able to count the labor cost.

\section{G. Prosperity}

The Act Number 13 in 2003 [4] stated, to increase the prosperity for labor force and their families, entrepreneur must provide the facilities of prosperity. The Government of the Regency of Batang asks for every company to provide the supported facilities of labor force prosperity that is labor force cooperative, mosque, milking place, shop, Social Guarantee Management Board (BPJS) of employment, transportation, Family Planning of Company, and Idul Fitri day incentive. There is no one company that has the complete facilities that is demanded by Government of the Regency of Batang. The coverage of BPJS in 2014 just reaches $80 \%$. In the Regency of Batang also still many of labor force with contract status that is reaches $35 \%$. It means that conducive condition of employment in the Regency of Batang in reality it is nor related with the enough prsperity, but it is because they still very needs the job.

\section{H. Industrial Relationship}

Industrial relationship in Indonesia is the industrial relationship that is based on the values of Pancasila. The Act Number 13 in 2003 [4] stated, in the implementation of industrial relationship, government has function to determine the policy, service, and punish the violation of manpower legislation regulation. The policy and program of industrial relationship that has been implemented by Government of the Regency of Batang as following: (1) routinely consuls the entrepreneur in order to develop the infrastructure of industrial relationship such as Indonesia Entrepreneur Association (APINDO), Indonesia Labor Force Association (SPSI), Bipartit, Tripartit, Company Regulation (PP), and Cooperation Regulation (PKB), but company that joins with the APINDO just 58\%, labor force association of company establishment, and industrial relationship $90 \%$ is bipartit, $78 \%$ companies have PP and just $20 \%$ companies have PKB; (2) periodically consul the labor force about the important of association; and (3) mediate the dispute of industrial relationship through the tract of nonlitigation (arbitrate).

\section{Work Termination( PHK)}

The Act Number 13 in 2003 [4] stated, the entrepreneur, labor force, labor force association, and government must try to avoid PHK. The Government of Regency of Batang also conducts the efforts of PHK prevention through the stages: (a) reduces the work extra times; (b) reduces wage; (c) reduces work hours; (d) put in the other company; (e) dismissal. If still happening PHK, Government of the Regency of Batang gives the direction to the labor force who gets PHK related with their rights that can be accessed from company such as dismissal money, reward money of work period, and other rights that are regulated in the legislation of manpower regulation or in PP and PKB that is in the company.

\section{J. Controlling}

Teh Act Number 13 in 2003 [4] stated, controlling of manpower is conducted by controller of labor force that has the competence and independence to guarantee the regulation implementation of manpower legislation. Controlling is conducted periodically by the Government of the Regency of Batang to all the companies or institution which have given the work opportunity to labor force, but there are still may of contradiction between the legislation regulation and with the management practice of labor force in the companies. It is the indication of inefficiency of controlling function. The limitation of controller seem to become the causes of ineffectiveness. Regency of Batang just has 1 (one) controller of labor force, meanwhile the company that must be controlled 184 companies. It is very bad ratio because its ideal is $1: 10$. The limitation of total controller is caused by the difficult to get the controller resources, because they have to have the certificate from the ministry and it is very difficult to get.

\section{CONCLUSION}

A. Management practice of labor force in Regency of Batang:

1. The Government of the Regency of Batang has not arranged the manpower plan, so the policy and program of employment that is determined in reality it has not been based on the employment plan.

2. Training and counseling are conducted through BLK that has been completed with curriculum, infrastructure of learning, but it has not fix trainer. The budget in every year is Rp. 120,000,000;

3. Performance of labor force deployment in Regency of Batang in 2014 reaches 5,148 people (34.90\%) from 14,750 applicants.

4. The distribution of job opportunity is conducted trough informal sector with the counseling way and increment of new business, autonomous labor force, and appropriate technology. Performance in 2014 reaches 290 people who have succeed to be entrepreneur.

5. The protection to the children labor force has been conducted well so Regency of Batang is stated as 
disserved children regency. Protection to the women labor force is conducted with forbidding the entrepreneur to uses the women labor force at night, but the protection to the physical defect labor force has not been conducted. The protection of K3 is determined through the program of Zero Accident.

6. Government of the Regency of Batang has determine the policy of UMK, but it just $75 \%$ company that obeys the policy.

7. There has not any company that provides the facility of complete prosperity. The coverage of BPJS is just $80 \%$ and the worker who their status still contract just $35 \%$.

8. Related with the industrial relationship, just $58 \%$ companies that joins with APINDO, labor force association all is established by companies, relationship of industrial $90 \%$ is bipartite, $78 \%$ companies have PP and just $20 \%$ it has PKB.

9. The Government of the Regency of Batang always prevents the occurrence of PHK through stages as following: (a) re duce work extra time; (b) reduces wage; (c) reduces work hours; (d) put in the other companies; (e) dismissal.

B. It needs the review for the manpower policy

in Indonesia:

1. States again the important to build the information system of employment, so the employment plan can be formulated well.
2. Determines nationally the total budget of employment management, so the management function of labor force can be conducted well.

3. Determines the standard of protection for the physical defect labor force.

4. Determines the strong sanction for the company which do violation to the UMK and the company which does not provide the prosperity facility and social guarantee of manpower.

5. Determines the standard of industrial relationship and determines the sanction to the companies that does not fulfill the standard.

Eases the regional government in providing the controller functional.

\section{REFERENCES}

[1] J. Kim, Strategic Human Resources Practice: Introducing Alternatives for Organizational Performance Improvement in the Public Sector, Public Administration Review, January/February, 2010

[2] S. Portillo \& 1.D. Davis, Gender and Organizational Rule Abidance, Maret/April 2009, 69, 2, Reseach Library Core Pg. 339

[3] N.M. Riccucci, The Pursuit of Social Equity In The Federal Goverment: A Road Less Traveled ?, Public Administration Review, May/June, 2009, 69, 3, Research Libraru Core Pg 373

[4] Undang-Undang RI Nomor 13 Tahun 2003 Tentang Ketenagakerjaan

[5] A.I. Strauss \& Y. Corbin, "Basic of Qualitative Research, London: Sage Publication, , 1990.

[6] Y.S. Lincoln \& E.G. Guba, "Naturalistic Inquiry”, Beverly Hills, CA: Sage Publications, Inc, 1985. 